\title{
Do dispositivo da sexualidade ao dispositivo da biotecnologia ${ }^{\star}$
}

\author{
Laura Belluzzo de Campos Silva $\star \star$ \\ Centro Universitário Paulistano, São Paulo, SP, Brasil
}

\begin{abstract}
Resumo
No livro "A vontade de saber", onde definiu o que chamou de dispositivo da sexualidade, Foucault deixou entrever que talvez outro dispositivo já estivesse em vias de se compor. Os avanços recentes no campo da biotecnologia molecular reabrem a discussão sobre as bases biológicas do comportamento, acenando com a possibilidade de novas formas de intervenção e com a de seu uso para fins comerciais. Partindo dessas idéias, este trabalho visa discutir que contribuições o conceito de biopoder pode trazer em relação aos recentes avanços da biotecnologia e cartografar algumas linhas que compõem esse novo dispositivo, que poderíamos chamar de biotecnológico.
\end{abstract}

Palavras-chave: Foucault; dispositivo; biotecnologia; mapeamento genético; mídia.

\section{From the dispositive of sexuality to the dispositive of biotechnology}

\begin{abstract}
In the book "The will to knowledge", where he defined what was called the dispositive of sexualitiy,Foucault made possible to glimpse that maybe another dispositive was about to be composed. The recent advances in the area of molecular biology reopen the discussion about the biological behavior basis. They consider the possibility of new intervention forms and their use for commercial purposes. Based on these ideas, this work aims to discuss which contributions the concept of biopower can bring in relation to the biotechnology advances and it maps some lines which compose this newdispositive, the ones could be called biotechnological.
\end{abstract}

Keywords: Foucault; dispositive; biotechnology; genetic screening; media.

E devemos pensar que um dia, talvez, numa outra economia dos corpos e dos prazeres, já não se compreenderá muito bem de que maneira os ardis da sexualidade e do poder que sustêm seu dispositivo conseguiram submeter-nos a essa austera monarquia do sexo, a ponto de votar-nos à tarefa infinita de forçar seu segredo e de extorquir a essa sombra as confissões mais verdadeiras (FOUCAULT, 1997, p. 149).

\section{Introdução}

Com a força e a beleza dessas palavras, Foucault encerrou $A$ vontade de saber, onde definiu o dispositivo da sexualidade, deixando entrever que talvez um outro dispositivo já estivesse em vias de se compor. Vários indícios nos fazem supor que já estejamos próximos de uma "outra economia dos corpos e dos prazeres" em que a sexualidade estaria deixando de ser o enigma a ser decifrado e em que o sexo, entendido como lado desconhecido de nós mesmos que nos domina e que precisamos conhecer, estaria deixando o lugar que ocupava, para cedê-lo a outros mistérios, até então insondáveis. Tudo nos leva a crer que a tecnologia do sexo, tal como Foucault definiu as práticas que se instauraram em torno da sexualidade no final do século XVIII, esteja sendo substituída por outras tecnologias que possibilitam ver o corpo de outras perspectivas, propiciando novas e inusitadas formas de intervenção. Os avanços da biotecnologia criam novas formas de intervenção na vida e de seu uso para fins comerciais

^Este trabalho apresenta parte do relatório final de pós-doutorado concluído pela autora em 2011, no Programa de Pós-Graduação em Psicologia Clínica da PUC/SP, que teve como Docente-Supervisor o Prof. Dr. Peter Pál Pelbart. A pesquisa original contou com um levantamento de dados empíricos a partir das notícias veiculadas em um jornal de grande circulação na cidade de São Paulo, que relaciona os avanços da biotecnologia molecular no campo da saúde humana às linhas do dispositivo biotecnológico.

$\star \star$ Endereço para correspondência: Centro Universitário Paulistano, Curso de Psicologia. Rua Madre Cabrini, 38 - Vila Mariana. CEP: 04020-000 - São Paulo, SP-Brasil.E-mail: laurabelluzzo@yahoo.com.br
O mapeamento do genoma humano já vem sendo considerado por alguns autores como um substituto natural do sexo, na medida em que exige o deciframento de um código que, ao ser desvendado, oferece respostas sobre quem somos, acenando, inclusive, com a possibilidade de decidirmos sobre o patrimônio genético de nossos filhos. A iminência desses saberes nos leva a supor que já estamos diante de um novo dispositivo, em que novos planos de visibilidade se descortinam, propiciando, àqueles que detêm o poder de utilizá-los, novos e exclusivos poderes. Mas um dispositivo não se compõe apenas de saberes científicos. Ele se constitui como um conjunto heterogêneo de discursos, instituições, leis, medidas administrativas, estudos científicos, proposições morais, filosóficas e filantrópicas. O dispositivo é a rede que se pode estabelecer entre esses elementos e pode ser entendido como um tipo de formação que em um determinado momento histórico tem a função principal de responder a uma urgência. Como afirma Deleuze (1989, p. 185):

Os objetos visíveis, os enunciados formuláveis, as forças em exercício, os sujeitos em posição são como vetores ou tensores. Assim, as três grandes instâncias que Foucault distinguirá sucessivamente, Saber, Poder e Subjetividade, não têm de maneira alguma contornos fixos, mas são correntes de variáveis em luta umas com as outras. É sempre numa crise que Foucault descobre uma nova dimensão, uma nova linha.

Tudo nos leva a crer que estamos diante de uma crise, em que novas linhas se apresentam, forjando a configuração de um novo dispositivo, que está a exigir aquilo que Foucault chamou de "trabalho sobre o terreno", que é o de, em cada caso, separar as linhas do dispositivo, desenhar um mapa, cartografar, medir a passos terras desconhecidas (DELEUZE, 1989, p. 185). 


\section{A noção de dispositivo}

A filosofia de Foucault apresenta-se frequentemente como uma análise de dispositivos concretos, sendo o dispositivo concebido como um emaranhado, um conjunto multilinear composto de linhas de natureza diferentes. Essas linhas não cercam ou delimitam sistemas que seriam homogêneos como o objeto, o sujeito, a língua, etc., seguem direções e traçam processos sempre em desequilíbrio, em que cada linha é quebrada, submetida a variações de direção e derivações (DELEUZE, 1989, p. 186). Os dispositivos são máquinas de fazer e de fazer falar. As dimensões do dispositivo que Foucault separa em primeiro lugar são as curvas de visibilidade e de enunciação. Mas a visibilidade a que Foucault se refere não remete a uma luz que viria iluminar objetos preexistentes. Cada dispositivo tem seu regime de luz, que se define pela maneira pela qual a luz cai, se expande e se esfuma, distribuindo o visível e o invisível e fazendo nascer ou desaparecer um objeto que não existe sem ela. Do mesmo modo, os enunciados remetem a linhas de enunciação sobre as quais se distribuem uma ciência, um gênero literário ou um estado de direito, que se definem através de regimes de enunciados que eles próprios fazem nascer. $\mathrm{O}$ dispositivo comporta ainda as linhas de força, que vão de um ponto a outro nas linhas precedentes, retificando-as, traçando tangentes e envolvendo os trajetos de uma linha a outra e que constitui a dimensão do poder. Por fim, Foucault descobre as linhas de subjetivação, que dizem respeito à invenção de modos de existir, cujo estudo é uma das tarefas fundamentais que deixou àqueles que o seguiriam (DELEUZE, 1989, p. 188).

\section{Linhas do dispositivo da sexualidade}

Ao ler o dispositivo da sexualidade segundo as linhas propostas por Foucault, podemos perceber como, a partir do final do século XVIII, surge uma nova luz que possibilita que se passe a ver na sexualidade problemas que doravante necessitarão de uma série de saberes e profissionais especializados em desvendar seus mistérios, situando-os na rubrica do normal ou patológico. Uma nova linha de visibilidade é criada e nesse regime de luz surgem objetos e formas de explicação para o que agora se torna visível, constituindo novas linhas de dizibilidade. Podemos localizar ainda as linhas de força, constitutivas do que Foucault designou de biopoder. Inicialmente voltado para o controle da saúde das populações, na sociedade disciplinar, o biopoder passa a ser exercido pelas diferentes instituições sobre os indivíduos, de modo a formatar corpos dóceis, necessários ao capitalismo que se desenvolve. Nesse dispositivo, produz-se um novo tipo de subjetividade, a do indivíduo que traz dentro de si uma interioridade única, uma alma incorporal, passível de ser disciplinada e apta a ser acessada por diferentes saberes e técnicas - como a Psicanálise, a Psicologia, a Psiquiatria, a Pedagogia, etc. Essas linhas parecem estar em mutação. Partindo da hipótese de que está se configurando um novo dispositivo, que poderíamos chamar de biotecnológico, este trabalho tem com objetivos: estabelecer algumas relações teóricas entre o conceito de bio- poder e os avanços recentes da biotecnologia no campo da saúde humana e cartografar as linhas que compõem esse novo dispositivo.

\section{Biopoder e biotecnologia}

Vários pesquisadores já vêm se debruçando sobre esse tema. Ao explicitar a razão de Foucault ter introduzido o tema da biopolítica na conclusão de sua obra sobre sexualidade, Pelbart (2003, p. 58, grifo nosso) aponta que talvez já estejamos deixando de ser a sociedade do sexo para nos tornarmos a sociedade dos genes:

Pois a sexualidade encontra-se precisamente neste entrecruzamento entre os dois eixos da tecnologia política da vida, a do indivíduo e da espécie, a do adestramento dos corpos e a regulação das populações, a dos controles infinitesimais, o micropoder sobre o corpo e as medidas massivas, estimações estatísticas, intervenções que visam o corpo social como um todo. De fato, o sexo faz a ponte entre o corpo e a população, a tal ponto que era a sociedade do sangue, correspondente ao poder de soberania, na era do biopoder torna-se sociedade do sexo (e depois, talvez, venha a tornar-se sociedade dos genes [...]).

A mesma questão reaparece na arguição feita pelo autor à dissertação de Sibilia, publicada em 2002 com o título de $O$ homem pós-orgânico: corpo, subjetividade e tecnologias digitais, quando Pelbart aponta que o grande salto dado pela pesquisa é:

[...] quando tematiza o lugar do código genético em substituição ao lugar de preeminência antes atribuído ao sexo, no contexto de um biopoder. Depois do sangue e do sexo é a vez dos genes... E tal como a sexualidade era um dispositivo não só de gestão de desvio mas de administração das diferenças, dos riscos, igualmente no âmbito genético se impõem essas 'terapias para normais', pois o risco está por toda parte e somos todos virtualmente doentes, ao que se segue essa administração do destino, todo um foco nas tendências, propensões, probabilidades, não naquilo que acontece, mas no que se é virtualmente, aquilo de que se é capaz - economia dos riscos, autopoliciamento, administração dos perigos, autocontrole, subjetividade empresarial (PELBART, 2003, p. 240).

Por sua vez, Bruno (1997), tomando como uma das tarefas de seu estudo avaliar a distinção entre a Modernidade e a Atualidade, elege as tecnologias biomédicas contemporâneas e a divulgação de suas descobertas pelos meios de comunicação, como signos que estariam sinalizando uma mudança no modo de ser do sujeito. Segundo Bruno, a colocação à disposição do público do grande estoque de possíveis que é o genoma está produzindo uma nova imagem do sujeito que o afasta do solo moderno. $\mathrm{O}$ olhar sobre o presente permite perceber certo estranhamento em relação àquilo que há cerca de um século supúnhamos natural: uma interioridade invisível ao olho e obnubilada para a consciência, mas penetrável pela palavra se com ela mantemos uma relação hermenêutica; uma memória genética imutável e uma memória psíquica capaz de ser resgatada; um corpo estranho à consciência, mas marcado pelo desejo inconsciente; um corpo que adoece malgrado si mesmo; um sujeito despossuído de 
si na medida em que sua verdade reside em seu inconsciente; uma sexualidade que age involuntariamente e em segredo, determinando um sujeito equivocado acerca de seu próprio desejo e uma técnica de objetivação do sujeito cujo instrumento fundamental é a enunciação de si. Para a autora, essas figuras do pensamento moderno estão se tornando cada vez menos familiares, tanto pelo interesse dos laboratórios em divulgarem suas pesquisas, como pelo espaço na mídia para divulgar reportagens ligadas à área biomédica e à saúde. As informações às quais, antes, só tínhamos acesso nos consultórios médicos, dos analistas ou no hospital psiquiátrico, hoje estão disponíveis e são anunciadas pelos meios de comunicação. Essas novas possibilidades são o retrato daquilo que estamos nos tornando.

De outra perspectiva, o impacto da velocidade com que a tecnologia está penetrando em nossas vidas é comentado por Laymert Garcia dos Santos. O autor afirma que "a avalanche tecnológica implica uma quebra de referências que muda a maneira como vemos o corpo, o que é homem, o que é mulher, o que é natureza humana e o que não é", concluindo que "nada do que hoje entendemos como humano irá sobreviver [...]" (MEYER et al., 2006, p. 12). O autor destaca que Foucault, no livro Nascimento da biopolitica afirma que, no neoliberalismo, o indivíduo deixa de se ver como trabalhador e passa a se ver como capitalista de si mesmo, em que todas as suas aptidões, qualidades, competências, etc. são considerados ativos financeiros que ele precisa valorizar. Laymert nos lembra que quando Foucault escreveu esse livro, em 1979, a genética ainda não havia explodido, mas Foucault já se perguntava como seria a cabeça desse indivíduo que pensa todos os seus recursos como ativos. E não apenas os recursos adquiridos, mas os que compõem o seu patrimônio genético também. Segundo Laymert, nessa obra Foucault estava abordando o nascimento de um novo tipo de eugenia, projeto do qual só acabou traçando um quadro geral, já que daí por diante derivou seus estudos aos cuidados de si (MEYER et. al., 2006, p. 17). Com efeito, em Nascimento da biopolítica, Foucault (2008) aponta que a eugenia hoje já não se refere mais à eugenia da raça e sim a uma eugenia distintiva, de investimentos diferenciados para melhoria do capital humano, seja em educação, seja em investimento afetivo diretamente relacionado ao tempo que os pais dedicam aos filhos até as migrações, etc. Ainda nesta obra, Foucault aponta que, na sociedade disciplinar, a intervenção sobre os indivíduos se dava pela norma e hoje se dá por uma intervenção ambiental (Foucault fica de voltar a esse ponto, mas não retorna, ao menos não nesta série de aulas):

Em segundo lugar, como vocês veem, (mas também tornarei sobre esse ponto), no horizonte de uma análise como essa, o que aparece não é em absoluto o ideal ou o projeto de uma sociedade exaustivamente disciplinar em que a rede legal que encerra os indivíduos seria substituída e prolongada de dentro por mecanismos, digamos, normativos. Tampouco é uma sociedade em que o mecanismo da normalização geral e da exclusão do não-normalizável seria requerido. Tem-se, ao contrário, no horizonte disso, a imagem ou ideia ou o tema-programa de uma sociedade na qual haveria otimização dos sistemas de diferença, em que o terreno ficaria livre para os processos oscilatórios, em que haveria uma tolerância concedida aos indivíduos e às práticas minoritárias, na qual haveria uma ação, não sobre os jogadores do jogo, e, enfim, na qual haveria uma intervenção que não seria do tipo da sujeição interna dos indivíduos, mas uma intervenção de tipo ambiental (FOUCAULT, 2008, p. 354, grifo nosso).

Não temos como saber o que Foucault quis dizer com a frase "uma intervenção do tipo ambiental", mas cremos que a "otimização das diferenças", mencionada por ele, poderia ser perfeitamente ilustrada pelo depoimento dado por James Watson, um dos descobridores da estrutura do DNA, na semana em que se comemoravam os 50 anos de sua descoberta. Nesse depoimento, Watson (apud LEITE, 2003, p. A 10) afirma que pessoas de baixa inteligência sem deficiência mental conhecida sofreriam de uma doença hereditária tão real quanto a hemofilia: "Se você for realmente burro eu chamaria isso de uma doença". E defende a melhoria da espécie pelo aperfeiçoamento genético, com uma justificativa ética: "Parece injusto que algumas pessoas não tenham essa oportunidade. Assim que houver um meio de melhorar nossos filhos, ninguém poderá contê-lo. Pais que aperfeiçoarem seus filhos... seus filhos vão dominar o mundo" (WATSON apud LEITE, 2003, p. A 10). O editor do artigo, Marcelo Leite (2003, p. A 10), critica a posição de Watson, afirmando que "a ciência ainda está muito longe de conseguir esse tipo de controle sobre as aptidões e o comportamento humanos". Leite considera ainda que, ao expressar essas ideias, Watson desconsidera a própria complexidade da genética, que não se resume ao esquema um gen/ uma doença, particularmente no caso de manifestações tão complexas e difíceis de definir como "inteligência" ou "burrice" (LEITE, 2003, p. A 10). Possível ou não, o fato é que o debate sobre a eugenia não só já foi retomado, nas bases em que Foucault apontou, como já está acessível ao homem comum, pelos meios de comunicação de massa. Recentemente, no programa Café Filosófico TV Cultura, de 7 de setembro de 2008, Benilton Bezerra afirmou que a eugenia hoje é um fato que não pode mais ser contestado: já não se discute mais se se pode ou não ser eugenista, porque isso todos nós já somos, mas quais as condições em que se pode procedê-la.

Voltando aos autores que partem do conceito de dispositivo da sexualidade, Michel Tort (2001, p. 22-23) destaca a importância desse conceito para compreender o que chamou de "dispositivos atuais do biopoder", afirmando que:

O projeto de análise do 'dispositivo de sexualidade' empreendido por Michel Foucault fornece uma orientação geral que não encontrou ainda um equivalente. A maior parte das questões atualmente em debate, envolvendo tanto os poderes da biomedicina, a medicalização e a transformação das condutas procriadoras quanto das práticas familiares, são nele ordenadas em conjuntos estratégicos, tanto do ponto de vista dos saberes quanto dos poderes que constituem. 
O alvo são as questões que as novas técnicas de procriação artificial colocam para alguns conceitos centrais da psicanálise, como o inconsciente, a ordem simbólica e a sexuação, além da clarificação do papel assumido pela psicanálise no dispositivo da sexualidade:

Em vez de servirem a 'reprodução' e sua ordenação social para celebrar a generalidade abstrata da Filiação instituída, o papel concedido à vida, à sua reprodução, surge tal como é no Ocidente desde o fim da era clássica, a saber, o momento em que a espécie entra como algo em jogo numa estratégia política, na qual se define uma biopolítica, um biopoder. A questão do sujeito já não se reduz a uma teoria geral do sujeito, do direito; torna-se a teoria dos procedimentos particulares de sujeição ligados ao avanço do biopoder. A própria representação da Lei e do Poder, inclusive na forma em que é metaforizada na teoria analítica, surge assim estreitamente vinculada a uma forma de poder histórico, jurídico-político, instituída normativamente no século XIX, mas desde então posta em xeque pelo desenvolvimento de formas bem diferentes de poder. [...] não se pode negar que as condições históricas de possibilidade da análise se enraízam num vasto movimento de dizer o sexo, o verdadeiro sobre o sexo; que a prática da psicanálise, por sua inserção nas intervenções psicológicas, biomédicas e psiquiátricas, participa do regime moderno da norma (TORT, 2001, p. 22, grifo nosso).

De outra perspectiva teórica, o filósofo italiano Giorgio Agamben (2004) propõe um aprofundamento da noção de biopoder, retomando a questão do ponto em que Foucault a deixou. $\mathrm{O}$ autor esclarece que os gregos não possuíam um termo único para exprimir o que nós dizemos com a palavra vida. Eles usavam dois termos: zoé, para designar o simples fato de viver, comum a todos os seres vivos, e bios, que se referia à maneira ou forma de viver própria de um indivíduo ou de um grupo. Embora no mundo clássico a vida natural (zoé) fosse valorizada como um bem, era excluída da polis e confinada ao âmbito do ôkkos. Assim, Aristóteles, no início de sua Política, distingue o chefe de um empreendimento - o oikonomos - e o chefe de família - o déspotes - do político. É também nesta obra, que Aristóteles define o homem como animal político, mas é preciso ter claro que político, para ele, não é um atributo do vivente como tal. Agamben (2004, p. 11) ressalta então que "é em referência a esta definição que Foucault, ao final de $A$ vontade de saber, resume o processo através do qual, nos limiares da Idade Moderna, a vida começa a ser incluída nos mecanismos e nos cálculos do poder estatal e a política se transforma em biopolítica, quando afirma":

Por milênios, o homem permaneceu o que era para Aristóteles, um animal vivente e, além disso, capaz de existência política; o homem moderno é um animal em cuja política está em questão a sua vida de ser vivente (FOUCAULT apud AGAMBEN, 2004, p. 11).

Segundo Agamben (2004, p. 11), para Foucault, o "limiar de modernidade biológica de uma sociedade" situa-se no ponto em que a espécie e o indivíduo enquanto simples corpo vivente tornam-se a aposta que está em jogo nas suas estratégias políticas. Para situar a questão que se propõe a desenvolver, Agamben destaca as ideias centrais que Foucault começa a focalizar a partir de 1977: a passagem do estado territorial para o estado de população e o consequente aumento da importância da vida biológica e da saúde da população como problema do poder soberano que progressivamente se transforma em governo dos homens, do qual resultam a animalização do homem, posta em prática através das mais sofisticadas técnicas políticas; a difusão das ciências humanas e sociais e a possibilidade de proteger a vida e de autorizar o holocausto. A essas colocações, o filósofo italiano contrapõe o pensamento de Hanna Arendt, apontando as dificuldades que o pensamento teria que superar para resolvê-las:

Por outro lado, já nos fim dos anos cinqüenta (ou seja, quase vinte anos antes de La volonté de savoir), Hannah Arendt havia analisado, em The human condition, o processo que leva o homo laborans e, com este, a vida biológica como tal, a ocupar progressivamente o centro da cena política do moderno. Era justamente a este primado da vida natural sobre a ação política que Arendt fazia, aliás, remontar a transformação e a decadência do espaço público na sociedade moderna. Que a pesquisa de Arendt tenha permanecido praticamente sem seguimento e que Foucault tenha podido abrir suas escavações sobre a biopolítica sem nenhuma referência a ela, é testemunho das dificuldades e resistências que o pensamento deveria superar neste âmbito. E justamente a essas dificuldades devem-se provavelmente tanto o fato de quem em The human condition, a autora curiosamente não estabeleça nenhuma conexão com as penetrantes análises que precedentemente havia dedicado ao poder totalitário (das quais está ausente toda e qualquer perspectiva biopolítica) quanto a circunstância, também singular, de que Foucault jamais tenha deslocado a sua investigação para as áreas por excelência da biopolítica moderna: o campo de concentração e a estrutura dos grandes estados totalitários do Novecentos (AGAMBEN, 2004, p. 12).

Ainda segundo o filósofo italiano:

A morte impediu que Foucault desenvolvesse todas as implicações do conceito de biopolítica, mas o ingresso da zoé na esfera da pólis - a politização da vida nua como tal constitui o evento decisivo da modernidade - que assinala uma transformação radical das categorias político-filosóficas do pensamento clássico (AGAMBEN, 2004, p. 12).

Para Agamben, os enigmas que o século XX propôs à razão histórica, dos quais o nazismo é só o mais inquietante, só poderão ser resolvidos no terreno em que foram intrincados, ou seja, o da biopolítica, para o que se faz necessária uma reflexão que interrogue sistematicamente a relação entre vida nua e política que governa a modernidade. Para ele, "se a política hoje parece atravessar um eclipse é porque se eximiu de um confronto com este evento fundador da modernidade" (AGAMBEN, 2004, p. 12). Explicitando que uma das orientações mais constantes do trabalho de Foucault é a de ter abandonado a abordagem tradicional do problema do poder baseada em modelos jurídico institucionais (a definição da soberania, a teoria do Estado) na direção de uma análise dos modos concretos com que o poder penetra nos corpos de seus sujeitos e em suas formas de vida, Agamben aponta que, nos últimos 
anos, esta análise se orientou segundo duas diretrizes de investigação: no estudo das técnicas políticas com as quais o Estado assume e integra em sua esfera o cuidado da vida natural dos indivíduos e no estudo das tecnologias do eu - por meio das quais se realiza o processo de subjetivação que leva o indivíduo a vincular-se à própria identidade $\mathrm{e}$ à própria consciência, e, conjuntamente, a um poder de controle externo. Para Agamben, embora estas duas linhas se entrelacem em vários pontos e remetam a um centro comum, o ponto em que estes dois aspectos do poder convergem, permaneceu, todavia, singularmente à sombra na pesquisa de Foucault, tanto que se pôde afirmar que ele teria se recusado a elaborar uma teoria unitária do poder:

Se Foucault contesta a abordagem tradicional do problema do poder, baseada exclusivamente em modelos jurídicos, ('o que legitima o poder'?) ou em modelos institucionais ('o que é o Estado'?) e sugere 'liberar-se do privilégio teórico da soberania' (Foucault, 1976, p. 80), para construir uma analítica do poder que não tome mais como modelo e como código o direito, onde está então, no corpo do poder, a zona de indiferenciação (ou, ao menos, o ponto de intersecção) em que técnicas de individualização e procedimentos totalizantes se tocam? E, mais, genericamente, existe um centro unitário no qual o 'duplo vínculo' político encontra sua razão de ser? Que exista um aspecto subjetivo na gênese do poder já estaria implícito no conceito de servitude volontaire em La Boétie; mas qual é o ponto em que a servidão voluntária dos indivíduos comunica com o poder objetivo? É possível contentar-se com explicações psicológicas do tipo: paralelismo entre neuroses internas e externas? E hoje, diante de fenômenos como o poder midiático espetacular será que é legítimo ou possível manter distintas tecnologias subjetivas e técnicas políticas? (AGAMBEN, 2004, p. 13-14, grifo nosso).

Para Agamben, tal orientação parece logicamente implícita nas pesquisas de Foucault, mas permanece um ponto cego - e é exatamente este oculto ponto de intersecção entre o modelo jurídico-institucional e o modelo biopolítico do poder que o filósofo italiano se propõe a investigar. $\mathrm{O}$ foco através do qual Agamben fará convergir os pontos de vista de Foucault e de Arendt será o conceito de "vida nua" ou "vida sacra":

Nele, o entrelaçamento de política e vida tornou-se tão íntimo que não se deixa analisar com facilidade. À vida nua e aos seus avatar no moderno (a vida biológica, a sexualidade, etc.) é inerente uma opacidade que é impossível esclarecer sem que se tome consciência do seu caráter político [...] (AGAMBEN, 2004, p. 126).

É em uma obscura figura do direito romano arcaico, a do homo sacer, que Agamben (2004, p. 16) encontra a chave para a compreensão do primeiro paradigma político do Ocidente. O homo sacer resulta da conjunção de dois aspectos: a impunidade da matança e a exclusão do sacrifício. É considerado homem sacro aquele que pode ser matável sem que sua morte possa ser caracterizada como sacrifício. O homo sacer se configura assim como a pessoa que é simplesmente posta para fora da jurisdição humana sem ultrapassar para a divina (AGAMBEN, 2004, p. 89). Agamben (2004, p. 92) estabelece uma analogia estrutural entre o poder soberano e o homo sacer, afirman- do que são figuras simétricas, que têm a mesma estrutura e são correlatas, no sentido de que soberano é aquele em relação ao qual todos os homens são potencialmente homini sacri e homo sacer é aquele em relação ao qual todos os homens agem como soberanos. Opondo-se neste ponto a Foucault, Agamben considera que a inserção da vida no poder não se inaugura com o advento da sociedade disciplinar, e sim já está presente no poder soberano:

Mais originário que o vínculo da norma positiva ou do pacto social é o vínculo soberano, que é, porém na verdade, somente uma dissolução; e aquilo que esta dissolução implica e produz - a vida nua - que habita a terra de ninguém entre a casa e a cidade - é, do ponto de vista da soberania, o elemento político originário (AGAMBEN, 2004, p. 98).

Para Agamben (2004, p. 107), é na figura do homo sacer, portanto, que nos encontramos diante de uma vida nua residual e irredutível, que deve ser excluída e exposta à morte como tal, sem que nenhum rito e nenhum sacrifício possam regatá-la. Relendo o princípio do mito de fundação da cidade moderna, Agamben conclui que o estado de natureza é, na verdade, um estado de exceção, em que o elemento originário é a vida e não a livre vontade dos cidadãos. Mas esta vida, explicita, não é simplesmente a vida natural reprodutiva, a zoé dos gregos, nem o biós, uma forma de vida qualificada, é, sobretudo a vida nua do homo sacer, zona de indiferença entre o homem e a fera, a natureza e a cultura (AGAMBEN, 2004, p. 115).

$\mathrm{O}$ rio da biopolítica que arrasta consigo a vida do homo sacer, corre de modo subterrâneo mas contínuo. É como se, a partir de um certo ponto, todo evento político decisivo tivesse sempre uma dupla face: os espaços, as liberdades e os direitos que os indivíduos adquirem nos seus conflitos com os poderes centrais simultaneamente preparam, a cada vez, uma tácita porém crescente inscrição de suas vidas na ordem estatal, oferecendo assim uma nova e mais temível instância ao poder soberano do qual desejariam libertar-se (AGAMBEN, 2004, p. 127).

No mesmo passo em que se afirma a biopolítica, assiste-se de fato, a um deslocamento e a um progressivo alargamento, para além dos limites do estado de exceção, da decisão sobre a vida nua na qual consistia a soberania. Se, em todo Estado moderno, existe uma linha que assinala o ponto em que a decisão sobre a vida torna-se decisão sobre a morte, e a biopolítica pode, deste modo, converter-se em tanatopolítica, tal linha não se apresenta mais hoje como um confim fixo a dividir duas zonas claramente distintas; ela é, ao contrário, uma linha em movimento que se desloca para zonas sempre mais amplas da vida social, nas quais o soberano entra em contato com o médico, com o cientista, com o perito, com o sacerdote (AGAMBEN, 2004, p. 128, grifo nosso).

Agamben demonstra então como alguns eventos fundamentais da história política da modernidade, como, por exemplo, as declarações dos direitos, que parecem representar uma incompreensível intrusão de princípios biólogico-científicos na ordem política (como a eugenética nacional socialista, com a sua eliminação da "vida indigna de ser vivida' ou o debate sobre a determinação normativa dos critérios da morte) só adquirem seu verdadeiro sentido quando são restituídos ao comum contexto 
biopolítico (ou tanatopolítico) ao qual pertencem. E é nesta perspectiva, diz ele, que o campo, como espaço biopolítico fundado sobre o estado da exceção, surge como paradigma oculto do espaço político da modernidade, do qual deveremos aprender a reconhecer as metamorfoses e os investimentos (AGAMBEN, 2004, p. 128-129).

Contra as colocações de Agamben, e a favor de Foucault, Ferreira (2008) nos ajuda a avançar na compreensão das relações entre o biopoder e as transformações tecnológicas contemporâneas. Considera o biopoder como uma das tentativas mais sistemáticas de pensar sobre o humanismo no contexto das transformações tecnológicas contemporâneas, em especial aquelas que dizem respeito ao controle, disciplina e regulação da vida. Destaca que a modernidade inaugurou uma nova forma de fazer política, cuja legitimidade não se estabelece mais no terreno da cultura, mas por meio de um controle sobre a vida biológica. Segundo o autor, Arendt e Heidegger abriram caminho para essas reflexões:

Arendt o faz ao criticar o que ela julga ser uma redução das possibilidades do político às questões econômicas da sobrevivência biológica, imediata - redução da "vida ativa ao labor", para usarmos o seu jargão. A crítica heideggeriana ao humanismo segue as mesmas pegadas. $\mathrm{Na}$ Carta sobre o humanismo Heidegger deixa isso claro: 'A metafísica pensa o homem a partir do animalitas, ela não pensa em direção da sua humanitas'. E já no Ser e tempo ele afirmava que 'o Dasein não deve jamais ser ontologicamente definido considerando-o como (ontologicamente indefinido) vida mais algo mais' (FERREIRA, 2008, p. 33).

Para o autor, é a partir dessas referências que Foucault depreende a oportunidade de pensar a dinâmica política moderna não mais a partir de uma perspectiva jurídica, tal como encontramos na teoria da soberania, mas a partir da ideia de administração biológica da vida. Cabe ao Estado garantir que o cidadão possa viver mais, de modo mais saudável e não mais estruturar sua ação a partir da questão: "que vida devemos julgar como digna de ser vivida?"

Analisando a leitura realizada por Agamben, Ferreira destaca alguns elementos problemáticos. Suas críticas se centram em três pontos: Primeiro: A tese de que o homo sacer seja uma figura paradigmática do pensar político no Ocidente precisa ser demonstrada, o que demandaria um esforço de reconstituição histórica bem maior do que o empreendido por Agamben até agora. Segundo: o mesmo pode ser dito acerca do uso de categorias centrais da teoria da soberania, já que elas só fazem sentido no âmbito de uma definição da dinâmica política que em última instância se reduz ao ato discricionário que estabelece uma separação clara, entre amigo e inimigo, por exemplo. Para Ferreira, Foucault abre uma perspectiva mais interessante, ao perceber formas de exercício do controle, da regulação e da disciplina que não provêm necessariamente de uma política centrada na ideia de identidade, da exclusão ou repressão da alteridade. Sobretudo em seus últimos escritos, o poder é para ele produtivo e não apenas repressivo. Por isso, embora não se possa negar que o campo de concentração é uma possibilidade do moderno, conforme afirma Agamben, não precisamos afirmar que ele seja sua essência ou expressão mais acabada. No terceiro ponto de sua crítica, Ferreira explicita que, embora leve em conta as ponderações feitas por Agamben acerca do exercício político contemporâneo, já que demonstram que a morte e a exceção ainda são questões fundamentais do humanismo, devem ser consideradas outras dimensões do biopoder. $\mathrm{O}$ autor se refere às biotecnologias de base molecular que vêm tornando problemática uma delimitação clara entre o vivo e o morto. Para ele, no nível de apreensão e organização da matéria em que ela atua, já não podemos afirmar que há uma separação clara entre o orgânico e o inorgânico, entre o animado e o inanimado, haja vista a possibilidade de sintetizar a vida por intermédio da nanobiotecnologia.

Rabinow e Rose (2003) também se dedicam a aprofundar as relações entre o conceito de biopoder e a biotecnologia. Os autores opõem-se tanto à visão de biopoder desenvolvida por Giorgio Agamben (2004) como à desenvolvida por Hardt e Negri (2002). Contestam a visão atribuída ao conceito de biopoder pelos autores de Império, afirmando que estes, partindo de sua leitura neo-marxista, definem o biopoder de uma perspectiva totalizante que parte da premissa que todo o trabalho que o poder exerce sobre a vida pode ser entendido como extração de algum tipo de valor ou mais-valia. Sem negar a necessidade de que as análises tradicionais da exploração econômica encampem sua relação com o caráter vivo das espécies humanas, e, talvez de todos os seres vivos, Rabinow e Rose questionam o poder de análise de um conceito de biopoder tão estendido. Concluem que a visão de Negri e Hardt apresenta-se como excessivamente maniqueísta, ao opor um Império global misterioso a uma multidão mais misteriosa ainda. Para eles, este diagrama é excessivamente antitético e esvazia o conceito de biopoder de sua força analítica. Rabinow e Rose ressaltam que o conceito de biopoder não é trans-histórico nem metafórico, mas efetivamente baseado em análises históricas ou genealógicas. Os autores apontam que é a partir do momento em que começa a desenvolver seu conceito de governabilidade para dar conta da variedade de maneiras de problematizar e agir nas condutas individuais e coletivas em nome de certos objetivos que não tinham o Estado como sua origem ou ponto de referência, que Foucault se distancia da visão de que este poder sobre a vida é indubitavelmente nefário, e este é o ponto de virada que o leva à fascinação pelos modos antigos de subjetivação e as possibilidades de liberdade. Em relação a Agamben, embora reconheçam que o Holocausto seja indubitavelmente uma configuração que o biopoder moderno pode assumir, discordam da tese de que este seja a figura exemplar da tanatopolítica ou a escura verdade escondida do biopoder:

O poder de comandar sob ameaça de morte é exercido pelos Estados e seus representantes em múltiplas instâncias. Em micro formas e em relações geopolíticas. Mas isso não significa dizer que esse tipo de exercício de poder baseado na ameaça de morte seja a garantia ou princípio de base de todas as formas de biopoder nas sociedades liberais contemporâneas. Ao contrário de Agamben, não pensamos que, $\mathrm{o}$ 
poder sobre a vida, do jurista, do médico, do cientista, do especialista, do padre, depende de uma aliança com o Estado. Nem é útil usar esse diagrama simples para analisar cada instância contemporânea da tanatopolítica, de Ruanda às mortes epidêmicas da AIDS na África. Certamente, a essência do pensamento crítico deve ser sua capacidade de fazer distinções que possam facilitar o julgamento e a ação (RABINOW; ROSE, 2003, online, tradução nossa, grifo nosso)

Embora reconheçam que os textos de Foucault permitem afirmar que é o biopoder que inscreve o racismo nos mecanismos do Estado, argumentam que o regime nazista foi um desenvolvimento paroxístico excepcional no qual o biopoder foi uma mistura complexa de política da vida e política da morte. Tanto que os médicos nazistas assumiram uma série de iniciativas voltadas ao cuidado com a saúde, e, naquele contexto, o passo para os campos da morte dependeu de outras condições históricas, morais, políticas e técnicas. Os autores também criticam o modo como Agamben trata a questão da soberania, pois embora concordem com o uso dessa interpretação para explicar os absolutismos do século XX, dos nazistas e de Stalin, consideram que, salvo em certos momentos paroxísticos, esse é um modo de poder cuja ativação só pode ser esporádica e não contínua. A totalização do poder soberano como um modo de ordenamento da vida cotidiana poderia ser extremamente custosa e os excessos do exercício desse poder tendem a ser compensados por sua natureza esporádica. A soberania, nesse sentido, é precisamente o diagrama de uma forma de poder e não a descrição de sua implementação. Algumas formas de poder colonial tentaram operacionalizá-la, mas em face de seus custos econômicos e governamentais, tomaram outra forma. Nenhuma forma de controle pré-moderna poderia deixar de notar a dependência da regra soberana, em sua forma não paroxística, de uma fina rede de convenções e obrigações recíprocas e de uma economia moral cuja complexidade e objetivo ultrapassam de longe o espetáculo da soberania. Os autores se referem ao fato de que, a partir do século XIX os Estados só podem governar porque se conectaram a aparatos que exercem demandas e limitam o poder central, como organizações sociais filantrópicas, pesquisadores sociais, grupos de pressão, médicos, feministas e grupos de reformadores que exercem um papel chave nesses governos. Desde o final da Segunda Guerra Mundial, uma série de agências dentro dos estados e de corpos transnacionais assumiu uma nova importância, de modo a formar comissões bioéticas, agências regulatórias e organizações profissionais. Todo um complexo bioético, enfim, no qual o poder dos agentes médicos para deixar morrer no final da vida, no começo da vida ou na reprodução, é simultaneamente aumentado pela tecnologia médica e regulado por outras autoridades como nunca antes. Além disso, surgem novos tipos de pacientes, grupos e indivíduos que cada vez mais definem sua cidadania em termos de seus direitos (e obrigações) com a vida, saúde e cura, bem como a configuração de novos circuitos de bioeconomia, onde ocorre uma capitalização da biociência em larga escala e a mobilização de seus elementos em novas relações de troca. Os novos conhecimentos moleculares da vida e da saúde vêm sendo mapeados, desenvolvidos e explorados por uma série de empresas comerciais, em alguns casos em aliança com os Estados, às vezes independentes destes, estabelecendo laços constitutivos entre vida, verdade e valor. Para Rabinow e Rose, uma mutação central diz respeito às relações entre o macro e o micro, ou, nas palavras de Deleuze, entre os planos molar e molecular desse modo de poder. $\mathrm{Na}$ era do estado social e naqueles locais em que o princípio organizador era o das lutas políticas, prevalecia o plano molar. Mesmo os Estados liberais tiveram um papel na batalha contra a degenerescência, impondo controles imigratórios, legitimando esterilizações compulsórias ou quase, encorajando organizações de aconselhamento para casamentos e procriação eugênicos. Cada uma dessas iniciativas tinha sua contrapartida molecular, como, por exemplo, a transformação da casa em uma máquina para saúde e a solicitação das mulheres no cuidado das crianças. Atualmente, muito dessa configuração permanece, e, na verdade, parte dela foi transferida para um nível supranacional nos esforços da União Europeia e do Banco Mundial; mas, com o declínio do domínio do social como um lugar privilegiado da objetivação nacional e intervenção nas sociedades liberais avançadas do Ocidente, emergem novas formações coletivas, novos modos de individualização e concepções de autonomia com seus direitos associados à saúde, vida, liberdade e busca de uma forma de felicidade que é cada vez mais entendida em termos corporais e vitais. Para os autores, "em nenhum outro lugar isso pode ser melhor exemplificado como nos eventos que envolveram o mapeamento do genoma humano" (RABINOW; ROSE, 2003, online, tradução nossa, grifo nosso). Os autores questionam de que modo poderíamos começar a pensar sobre as implicações dos avanços nascentes das tecnologias genômicas e moleculares, já que é evidente que a crença de que alguma coisa significativa está em destaque mobiliza as estratégias e táticas de uma grande variedade de forças. Os governos nacionais investem em genômica e os fundos de pesquisa investem em medicina genômica aplicada e básica. Companhias farmacêuticas e biotecnológicas investem milhões e empregam milhares de cientistas e técnicos em experimentos e em invenções. Grupos de pacientes investem esperança, capital político, suas próprias amostras de tecidos e dinheiro na pesquisa de tratamentos genéticos. Para Rabinow e Rose (2003, online, tradução nossa, grifo nosso):

é evidente que está se formando uma nova racionalidade biopolítica em relação à saúde, na qual conhecimento, poder e subjetividade estão entrando em novas configurações, algumas visíveis, outras potenciais. Para os pesquisadores, os três elementos trazidos juntos no conceito de biopoder - o conhecimento dos processos de vida essenciais, as relações de poder que tomam os humanos enquanto seres vivos como seus objetos, e os modos de subjetivação através dos quais os sujeitos trabalham sobre si mesmos enquanto seres vivos - esperam para serem patenteados. Para isso, a análise de clarificar a racionalidade biopolítica do futuro próximo deve transpor extensos inquéritos detalhados empiricamente em mudanças que estão ocorrendo em cada um dos 


\section{três eixos bem como nas relações e combinações entre eles.}

Para os autores, uma das mais urgentes demandas de pensamento crítico hoje é a invenção, a amplificação e o exame de uma caixa de ferramentas analítica adequada à realidade atual, na qual o biopoder, usado de um modo preciso e submetido a um desenvolvimento inventivo, deverá ser parte essencial. Em publicação mais recente, Rose (2007) caracteriza a biopolítica contemporânea, comparando-a à biopolítica anterior. A especificidade da biopolítica da primeira metade do século XIX estava nas ligações estabelecidas entre população, qualidade, território, nação e raça. A saúde era entendida em termos de qualidade - do indivíduo e da raça - e a qualidade era entendida de uma maneira quase evolucionária, como adaptação. A adaptação da população era suscetível a ameaças de dentro e de fora, e os governos nacionais tinham a obrigação de proteger as nações contra essas ameaças e de tomar medidas para aumentar a adaptação por meio de políticas formuladas e garantidas por lei pelo aparato do estado. A eugenia foi estruturada em termos da importância política relacionada à capacidade de adaptação da população considerada em massa, na medida em que ela competia com outras populações nacionais e se baseou no discurso de verdade da biologia das quatro primeiras décadas do século XX. Mas aquela verdade foi transformada. No final da Segunda Guerra Mundial, muitos intelectuais e cientistas trabalharam para desfazer as ligações entre a saúde genética dos indivíduos e a qualidade da população em massa. Os geneticistas refletiram sobre seu passado e direcionaram suas pesquisas para a busca das origens das doenças. A norma da qualidade da população foi substituída pela da saúde individual. Os geneticistas deixaram de pensar em categorias sociais amplas e passaram a aprofundar seus conhecimentos nos determinantes subjacentes à patologia e normalidade, os genes e seus modos de funcionamento ao nível molecular. Essa molecularização é central para o estilo de pensamento da biologia contemporânea, e, portanto, para as práticas e políticas da biomedicina contemporânea. Por conta disso, as racionalidades políticas de nosso presente não são mais inspiradas pelo sonho de tomar conta da vida de cada um em nome do destino de todos. O ideal de um estado que coordenaria todos os negócios da sociedade caiu em desuso, entrando em seu lugar outro tipo de estado:

hoje, a razão para o interesse político na saúde da população não está mais estruturada em termos das consequências da inadaptação da população como um corpo orgânico para a luta entre nações. Em vez disso, ele é posto em termos econômicos, dos custos da doença em termos de dias de trabalho perdidos, ou do pagamento de seguros, ou em termos morais, do imperativo para reduzir as desigualdades em saúde. Enquanto as comparações internacionais ainda são indubitavelmente significantes, sua função política contemporânea não é mais a de marcar a vulnerabilidade potencial de uma política na rivalidade geopolítica; elas servem muito mais como índices públicos da extensão na qual as nações têm instituído políticas para o governo da saúde. Os indicadores da saúde nacional, aqui, não medem a adaptação da população como um todo; eles funcionam como agregados do status de saúde de cidadãos individuais e de famílias. Portanto, nesse tipo de saúde, a relação ideal do estado em relação ao povo, não é mais inspirada pelo estado 'social'. O estado contemporâneo não 'nacionaliza' a corporeidade de seus sujeitos em um corpo político no qual ele trabalha em massa, em relação com o corpo político de outros estados competindo em termos similares. $\mathrm{O}$ estado não mais espera resolver as necessidades de saúde da sociedade. A vitalidade das espécies - a nação, a população, a raça - é raramente a razão e a legitimação para intervenções compulsórias nas vidas individuais daqueles que são apenas seus elementos constituintes. Nesse domínio e em muitos outros, as imagens agora são as de um estado capacitador, facilitador, do estado como um animador (ROSE, 2007, p. 63, tradução nossa, grifo nosso).

Para Rose, o espaço da biopolítica contemporânea não foi formado por um único evento, mas é marcado por pelo menos cinco passagens em que mutações significativas estão ocorrendo: 1. Molecularização: a biomedicina contemporânea concebe a vida em um nível molecular, como um conjunto de mecanismos vitais inteligíveis entre entidades moleculares que podem ser identificadas, isoladas, manipuladas, mobilizadas, recombinadas em novas práticas de intervenção que não estão mais constrangidas pela aparente normatividade de uma ordem vital natural. 2. Otimização: as tecnologias da vida contemporâneas não são mais restritas pelos polos da saúde e da doença, pois embora esses dois polos permaneçam, muitas intervenções parecem agir no presente para assegurar o melhor futuro possível para aqueles que são seus objetos. Disso decorre que tais tecnologias disputam visões do que pode ser considerado um estado ótimo na vida humana. 3. Subjetificação - Trata-se da emergência de novas ideias sobre o que os seres humanos são, sobre o que eles poderiam fazer e o que podem esperar. Novas concepções de "cidadania biológica" vêm sendo forjadas, recodificando deveres, direitos e expectativas de seres humanos em relação a suas doenças e as suas vidas, reorganizando as relações entre indivíduos e autoridades biomédicas e reconfigurando as formas como seres humanos referem-se a si mesmos como indivíduos somáticos. 4. Expertise somática: Esses desenvolvimentos estão dando origem a novas formas de governar a conduta humana e a múltiplas subprofissões que exigem expertise e exercitam seus diversos poderes no manejo de aspectos particulares de nossa existência somática: geneticistas especializados em determinados tipos de doenças, trabalhando em aliança com grupos de pacientes e famílias, especialistas em medicina reprodutiva com suas clínicas públicas e privadas, terapeutas de células embrionárias, etc. Ao lado desses experts do grupo "soma" existe toda outra extensa gama de experts pastorais - dos quais os conselheiros genéticos talvez sejam os melhores exemplos - cujo papel é aconselhar, guiar, cuidar e dar suporte a indivíduos e famílias, enquanto estes negociam a seu modo os dilemas éticos, médicos e pessoais que enfrentam. 5. Economia da vitalidade: trata-se do delineamento de um novo espaço econômico - o da bioeconomia, e de uma nova forma de capital - o biocapital, que surgem a partir da busca de biovalor e das ligações 
que se formaram entre verdade e capitalização, entre as demandas de valor para os acionistas e o valor humano investido na esperança da cura e otimização. A vida em si tornou-se disponível para essas novas relações econômicas, uma vez que a vitalidade foi decomposta em uma série de distintos e discretos objetos - que podem ser isolados, delimitados, estocados, acumulados, mobilizados e trocados segundo um valor discreto, transportados ao longo do tempo, espaço, espécies, contextos e empresas, a serviço de muitos objetivos distintos. Rose afirma que, embora nenhuma dessas mutações marque uma quebra fundamental com o passado, já que cada uma delas exibe continuidade ao lado da mudança, uma nova configuração está se formando do entrelaçamento dessas cinco linhas. Para Rose, a mobilização da vitalidade não é nova, nem sua combinação, haja vista a longa história da coleta e geração de plantas. Tampouco a molecularização é suficiente por si só, para fazer circuitos de vitalidade. Para o autor:

O que é crucial, para os presentes propósitos, é que a 'biopolítica molecular' agora diz respeito a todas as maneiras pelas quais os elementos da vida podem ser mobilizados, controlados e ter suas propriedades acordadas e combinadas em processos que não existiam previamente. É nesse nível molecular, portanto, que a vida em si começa a se tornar aberta à política. (ROSE, 2007, p. 15, tradução nossa, grifo nosso).

Para Rose, no novo campo da biopolítica que se configura a biologia não é destino, mas oportunidade. Oportunidade de descobrir as bases biológicas de uma doença, da infertilidade, de evitar uma reação adversa a drogas, de gerar filhos livres de doenças incapacitantes, etc. Com isso, argumenta, estamos assistindo o surgimento de uma nova ética somática, imbuída de esperança, orientada para o futuro e demandando ação no presente. Por um lado, nossa vitalidade foi aberta, como nunca antes, à exploração econômica e extração de biovalor, em uma nova bioeconomia que altera nossa verdadeira concepção de nós mesmos. Por outro lado, nossa individualidade somática, neuroquímica e corpórea tornou-se aberta à escolha, à prudência e responsabilidade, à experimentação e contestação, e assim à política da vida em si. Para Rose, assim como Max Weber encontrou uma afinidade eletiva entre a ética protestante e o espírito do capitalismo inicial, há uma afinidade eletiva entre a ética somática contemporânea e o espírito do biocapitalismo. Ética somática que consente com a virtude moral particular para realizar pesquisas que visam obter benefícios por meio do manejo da vida, ao mesmo tempo em que abre as mais moralistas das condenações para aqueles que considera causadores de prejuízos à saúde, em nome do lucro.

\section{Cartografando o dispositivo da biotecnologia}

A biotecnologia é um conjunto de técnicas de manipulação de seres vivos ou partes destes para fins econômicos. Segundo as técnicas de que se utiliza divide-se em tradicional e moderna. A biotecnologia moderna surgiu no início da década de 1970 e sua evolução teve início em 1953 quando James Watson e Francis Crick publicaram o modelo da estrutura do DNA. A biotecnologia moderna inclui as técnicas de transferência e modificação genética direta (conhecida como engenharia genética ou tecnologia do DNA recombinante), a genômica, que consiste no mapeamento dos genomas, e, atualmente se encontra na fase pós-genômica, cujo desenvolvimento está centrado na análise funcional de genes sequenciados, mas de função ignorada, e nos mecanismos de interação e regulação entre eles (SILVEIRA; BORGES; BUAINAIN, 2005; SILVA, 2000). Com a descoberta de Watson e Crick, nosso olhar foi dirigido para a complexidade da estrutura e funcionamento dos genes, pequenas unidades responsáveis pela transmissão dos caracteres hereditários, cuja descoberta, por Mendel, em 1865, deu origem à genética moderna. A conclusão do Projeto Genoma Humano favoreceu uma série de investigações relacionadas à identificação de genes causadores de doenças, sobre os mecanismos de sua manifestação, sua transmissão e de seu possível tratamento ou prevenção, e talvez, em fases mais avançadas da investigação, ao estudo de sua influência sobre certas tendências, habilidades ou capacidades das pessoas (CASABONA, 2002).

$\mathrm{Na}$ sociedade atual, que Foucault denominou de sociedade de controle, o sujeito é modulado como uma moldagem autodeformante que muda continuamente. Segundo Bernardes e Guareschi (2007), o corpo anatomossomático da sociedade disciplinar passa a ser visto como um corpo genético e essas modificações se dão por meio do consumo e das biotecnologias. Modificar o próprio corpo torna o indivíduo um empreendedor de si mesmo, um sujeito saudável. Tomada pelas biotecnologias, a saúde torna-se objeto de consumo, gerando a ideia de controle sobre os corpos e as existências. O empreendedorismo em relação à própria saúde torna-se uma tecnologia de si, produzindo subjetividades que consomem biotecnologias como forma de controle do corpo e da vida. A manipulação genética traz como possibilidade a criação de "eus" particulares, frutos de escolhas e intervenções:

As intervenções tecnocientíficas voltam-se não para uma dimensão epistemológica, mas sim, para uma dimensão biológica de si. Essa dimensão biológica de si, esse eu biológico, não define mais o limite da existência, mas a possibilidade de manipulação das condições de existência. $\mathrm{O}$ eu como fato da vida é passível de transformação, pode agora transformar-se no que quiser, essa é a subjetividade no contemporâneo. A intervenção genética, assim como cria categorias de "eus" por meio dos traços estabelecidos geneticamente (personalidade, caráter, constituição física, predisposições, etc), inventa a possibilidade de agir sobre o fato da vida: o gene dá origem à vida, mas por meio do gene podem-se modificar as condições de vida. Cria-se a ideia de que agora é possível escolher o que se quer ser (BERNARDES; GUARESCHI, 2007, p. 156).

$\mathrm{O}$ espaço cada vez maior que vem sendo dado às biotecnologias na produção de formas de pensar e relacionar-se consigo mesmo está fortemente relacionado ao papel exercido pela mídia, que se torna um vetor de biotecnologização, na medida em que constrói os sentidos de como e quanto devemos experimentar e necessitar os avanços biotecnológicos, principalmente no que tange à 
saúde. Por meio de diferentes estratégias, coloca em discurso a relação saúde e biotecnologias, forjando os modos como devemos conceituar a saúde e experimentá-la (BERNARDES; GUARESCHI, 2007).

\section{Considerações finais}

Os avanços desenvolvidos pela biotecnologia criam novas linhas de visibilidade dando origem ao que Rose denominou de molecularização da vida. Novas linhas de força vão sendo traçadas pelas relações que se estabelecem entre esses avanços e os investimentos de empresas de capital. O cuidado com a saúde dirige-se para a qualidade de vida dos indivíduos que são responsabilizados por cuidar de sua saúde e estimulados, em grande parte pela mídia, a modular, otimizar e customizar seus corpos. Novas tecnologias de si se instauram, gerando novas formas de subjetivação. Tudo isso no faz crer que estamos diante de um novo dispositivo que podemos chamar de biotecnológico.

\section{Referências}

AGAMBEN, G. Homo sacer: o poder soberano e a vida nua. Belo Horizonte: UFMG, 2004. v. 1.

BERNARDES,A. G.; GUARESCHI, N. Estratégias de produção de si e de biotecnologias. Psicologia em Estudo, Maringá, v. 12, n. 1, p. 151-159, jan./abr. 2007. Disponível em: <http:/ www.scielo.br/scielo.php? script=sci_arttext\&pid=S1413$73722007000100018 \& \operatorname{lng}=$ pt\&nrm $=$ iso \& tlng=pt\&user $\mathrm{ID}=-2>$. Acesso em: 10 jul. 2011.

BRUNO, F. Do sexual ao virtual. São Paulo: Unimarco, 1997.

CASABONA, C. M. R. La genetíca y la biotecnología em las fronteras del derecho. Actabioéthica, Santiago, v. 8, n. 2, p. 283-297, 2002. Disponível em: <http://www.scielo.cl/scielo. php?pid=S1726-569X2002000200009\&script=sci_arttext $>$. Acesso em: 10 jul. 2011.

DELEUZE, G. Qu'est-ce qu'un dispositif? In: Michel Foucault philosophe. Rencontre internationale. Paris (9, 10, 11 janvier) 1988. Paris: Seuil, 1989. p. 185-193.

FERREIRA, J. Humanismo, biopoder e soberania: elementos para uma discussão das biotecnologias contemporâneas. Ciência e cultura, São Paulo, v. 60, n.1, p. 32-35, jan./mar. 2008. Disponível em: <http://cienciaecultura.bvs.br/scielo, php?pid=S0009-67252008000100014\&script=sci_arttext $>$. Acesso em: 10 jan. 2011.

FOUCAULT, M. História da sexualidade: a vontade de saber. Rio de Janeiro: Graal, 1997. v. 1.

FOUCAULT, M. Nascimento da biopolitica (1979). São Paulo: Martins Fontes, 2008.

HARDT, M.; NEGRI, A. Império. Rio de Janeiro: Record, 2002.

LEITE, M. Burrice é genética, arrisca James Watson. Folha de São Paulo. São Paulo, 4 mar. 2003. Primeiro Caderno, p. A10.

MEYER, A. V. et al. Aceleração tecnológica e quebra de representações. Ide: Psicanálise e Cultura: Biotecnologia, São Paulo, v. 29, n. 43, p. 8-18, 2006.

PELBART, P. P. Vida capital: ensaios de biopolítica. São Paulo: Iluminuras, 2003.
RABINOW, P.; ROSE, N. Thoughts on the concept of biopower today. 2003. Disponível em: <http://www.lse.ac.uk/sociology/ pdf/RabinowandRose-BiopowerToday03.pdf $>$. Acesso em: 5 ago. 2009.

ROSE, N. The politics of life itself: biomedicine, power, and subjectivity in the twenty-first century. New Jersey: Princeton University Press, 2007.

SIBILIA, P. O homem pós-orgânico: corpo, subjetividade e tecnologias digitais. Rio de Janeiro: Relume-Dumará, 2002.

SILVA, L. H. P. da. Ciências biológicas e biotecnologia: realidades e virtualidades. São Paulo em Perspectiva. v. 14, n. 3. p. 60-67, 2000. Disponível em: <http://www.scielo.br/scielo. php?pid $=$ S0102-88392000000300011\&script $=$ sci_arttext $>$. Acesso em: 3 jul. 2009.

SILVEIRA, J. M. F.; BORGES, I. C.; BUAINAIN, A. M. Biotecnologia e agricultura: da ciência e tecnologia aos impactos da inovação. São Paulo em Perspectiva, v. 19, n. 2, p. 101-114, abr./jun. 2005. Disponível em: <http://www.scielo. br/scielo.php?pid=S0102-88392005000200009\&script=sci arttext>. Acesso em: 3 jul. 2009.

TORT, M. O desejo frio. Rio de Janeiro: Civilização Brasileira, 2001.

Recebido em: 10 de setembro de 2012 Aceito em: 10 de setembro de 2015 